\title{
Zimbabwean Female Participation in Physics: The Use of Drawings in Documenting Students' Images of Scientists
}

\author{
Gudyanga Anna a* \\ a Department of Educational Foundations Management and Curriculum Studies, Midlands State University, Gweru, \\ Zimbabwe, Tel: +263 782737372 \\ *Corresponding author's email address: gudyangaa@msu.ac.zw/gudyangaa@gmail.com
}

\author{
A R T I C L E I N F O \\ Received: 26-10-2016 \\ Accepted: $19-12-2016$ \\ Keywords: \\ Drawing; \\ Identity Formation; \\ Participation; \\ Physics Identity; \\ Scientist.
}

Available online: 10-01-2017

JEL Classification:

\begin{abstract}
A B S T R A C T
The study investigated the Zimbabwean female adolescent students' images of scientists and the influence of their perceived images on their participation in physics. Three high schools that were offering physics at A-level were targeted. Four female students eighteen years and above: three doing mathematics and physics and one doing physics without mathematics were purposively chosen. The data generating instruments were classroom observation guide and drawing. Findings show that two out of four female students drew stereotypical image of a male scientist and listed Eurocentric names of male scientists. The other two female students, gave African names to the scientists that they drew and this may suggest that scientists are not only Eurocentric but can also be Afrocentric. Their diagrams might denote a positive physics perception which may have resulted in the construction of a positive identity formation regarding physics. The positive physics identity in turn may indicate that the female participants were more attuned to continue studying physics. However, the female students did not seem to perceive scientists as ordinary people but as famous inventive people they encountered in their science text books. This study also contributes to the strengthening of educational research in Zimbabwe, especially research aimed at emancipation of female students. The findings may create the need in heads of schools to sensitise academic staff on the gender dimensions of teaching and learning, which is an important first step towards the transformation of cultural perceptions in order to enable female students to realise their full potential.
\end{abstract}

This is an open access article under the terms of the Creative Commons Attribution License 4.0, which allows use, distribution and reproduction in any medium, provided the original work is properly cited.

\subsection{Introduction}

"The year is 1976, I am both excited and nervous to be in the Ordinary Level (O-level) A-Stream, or more commonly known as the science stream. What a prestige and honour! Very few students make it into this stream, but I had done well in Mathematics and Science, so I have earned this. So here I am with nine other girls and forty boys ready to be received by our teachers. It did not immediately dawn on me that the girls were in a minority, or that they were not seen as part of the group, until a male physics teacher walked in and enquired, "Why are you girls in this class? You must work very hard you girls." His words left me daunted and overwhelmed and so began the year with the girls feeling unwanted and misplaced, in this stream. I remember the first time one of the girls failed to answer a question. His [the teacher's] words were piercing, "You have to pull up your socks, work harder to get it right. Stop wasting our time here." It seemed unfair 
because when one of the boys got an answer wrong, the same teacher chided him lightly, "Not really the answer, but..."

I stuck the first month with gritted determination although the classroom continued to be an uninviting, cold and hostile place. The fear of being there was enough and to do practical classes in physics was the worst! I would go in and the teacher would constantly sit near me as if watching every move, I made. His presence caused me to shake and shiver with nervousness. I was so overwhelmed that I couldn't concentrate. I started sweating profusely and began to fumble. Before long a loud shattering noise filled the air... something had fallen off my table. I didn't even look up and wait for him to respond. I just ran.

The shattering of the glassware was to resemble my broken dreams. After the incident in the laboratory, I immediately withdrew from the course even though I knew that this decision would be one I would regret forever.

It's 2014, almost 40 years later. Are things any different today?" (Journal Entry, September 2014)

Whenever I think of my experiences as an adolescent female student, both in a physics classroom and the physics laboratory, I believe that what happened to me was dehumanising. The teacher's attitude and behaviour was Antithical to the Unhu/Ubuntu ${ }^{1}$ philosophy that underpins and guides the African way of life. The concept of Ubuntu is an ancient African philosophy which comes from isiZulu and isiXhosa languages which means "living in humble humanity with other people" (Nafukho, Amutabi, \& Otunga, 2005, p. 11). This is clearly articulated when the authors state that "an individual is an individual because of other individuals in society." Ubuntu, therefore, focuses on character formation as the cornerstone and recognises the human being as a social being whose worldview and identity are shaped by interacting with fellow human beings (Nafukho, 2006). Character formation shapes one's identity, that is, how an individual perceives himself/herself, be it at home or at school. Thus, for education to be meaningful, it must respond to the needs of a people (including females) and their worldviews. The worldview in turn guides teachers' actions in relation to how they teach, what they teach, and the kind of classroom climate they create (Muropa, Kusure, Makwerere, Kasowe, \& Muropa, 2013). Considering that the spirit of Ubuntu permeates all spheres of African life, gender prejudices of any nature in the wider society particularly in the classroom situation can be seen as an anomaly. Therefore, from the Ubuntu perspective, my experiences in the physics classroom are difficult to understand. However, literature suggests that gender discrimination in an educational environment is not unique to Zimbabwe but a global issue (Kalu, 2005; Zohar \& Bronshtein, 2005).

In this context, it is interesting to note that the 2013 Human Development Report ${ }^{2}$ revealed that the Gender Inequality Index for Zimbabwe in 2012 was 0.583 , ranking the country number 116 out of 148 countries surveyed (National Gender Policy, 2013). In view of the fact that women constitute about $52 \%$ of the total population in Zimbabwe, (National Gender Policy, 2013) under-representation of females, as indicated by the Gender Inequality Index, can have serious consequences to the economic development of the nation. Against this background, my focus was to use drawings in documenting female students' images of a scientist and the influence of their perceived images on their participation.

Female students are under-represented in science when Zimbabwe needs more scientists to meet its developmental agenda in a technological world. I was motivated to carry out this study by low enrolment of females in science in high schools which eventually leads to fewer females opting to choose science at tertiary levels. In an effort to effectively transform the provisions of regional and international legal and human rights instruments to address the issue of gender discrimination, the Zimbabwean government launched the National Gender Policy (NGP) in 2004. One of the goals of the NGP was to:

"Eliminate all forms of discrimination against boys and girls in education and skills training which includes science and technology as well as to promote and encourage girls to take on science, mathematics and technology at all levels of education" (National Gender Policy, 2004, p. 10).

Despite both international and national recognition and concern for the lower numbers of women participating in physics, changes in policy seem to be making little if no difference on the ground. In considering the underrepresentation of females in physics, this study focuses on identity formation as a possible driver for participation in physics. A deeper understanding of the under-representation within the context of identity and identity formation could provide tangible clues as to what change parameters would influence a shift in perception amongst young women. The country as a developing nation cannot afford to waste human resources by ignoring

\footnotetext{
1 Ubuntu in the Zimbabwean context is the same as Unhu

2 Produced by the United Nations Development Programme, 2012 cited by National Gender Policy, 2013
} 
the lack of participation of women [who make up half the population] in important scientific disciplines. In fact, there is hardly any study that focuses on the relationship between female identity and their participation in physics. There is therefore need to consider female students' images of a scientist and the influence of their perceived images on their participation in physics and hence, this is the gap in the research that this study seeks to address. Thus, the focus of the current study is encapsulated in the research questions described below.

- What are female students' images of a scientist?

- What is the influence of these perceived images on their participation?

In order to finally provide answers to the research questions, there is need to consider what identities are. According to Knight, Bernal, Garza, and Cota (1993), identities may be conceptualised as memory structures composed of schemas and that these schemas are self-theories that guide information processing by structuring experiences that control behaviour. A schema can also be defined as a collection of inter-associated mental representations that function together as a unit (Horowtz, 2010). It is, therefore, a mental concept that informs female students about what concept from a variety of experiences are then stored in memory (Leary \& Tangney, 2003). Our brains create and use schemas as a short cut to make future encounters with similar situations easier to navigate. In relation to my study, schemas enable female students to form an identity or self-concept with respect to physics. The self-descriptions made by female students holistically contribute towards developing and eventually achieving a physics identity. While an attempt is made to address these questions from the perspective of female adolescent students, the next section reviews literature i.e. a brief overview of the concept 'gender and identity, gender development theories' and the di-hybrid theoretical lens that informs this study are explained.

\subsection{Literature review}

My introductory narrative depicts a common incident in the context of gender discrimination in science classrooms in many countries (Hazari, Sonnert, Sadler, \& Shanahan, 2010; Lips, 2008; Mwetulundila, 2011). Based on a review of a number of studies, Murphy and Whitelegg (2006b, p. 23) reported that in physics classrooms, "teachers spent more time interacting with boys, valued boys' experiences more in the classroom and generally treated boys more favourably than they treated girls." They further found that teachers' practices are key in influencing female students' experiences and attitudes to science and to physics in particular.

Although a large number of western studies (Coyle, 2006; Murphy \& Whitelegg, 2006a; Olorode, 2005) have reported on the reasons for low uptake of physics by girls, very few studies have been carried out in developing countries. There is therefore a need to carry out this type of research in a developing country like Zimbabwe where cultural gender role patterns are distinct and pervasive. The focus of studies in western countries have been predominantly on school, classroom and student factors (Carlone \& Johnson, 2007; Hazari et al., 2010; Hughes, 2001; Walker, 2001) with hardly any study examining the role of identity with regard to female students' interest in science. In fact, there are no studies that focus on the relationship between female students' identity and their participation in physics, specifically considering female students' images of a scientist and the influence of their perceived images on their participation in physics and hence, this is the gap in the research that this study seeks to address. The next section considers the concept 'gender and identity,

\subsection{Gender and identity}

The term identity is derived from the Latin word identitas, which is derived from the word idem, meaning, the same, (Petersoo, 2007, p. 117). The term is defined differently by various theorists who attempt to explain it. For example, Castells (2004, p. 6) defines identity as, "people's source of meaning and experience," while Jenkins (2004, p. 4) argues that all human identities are essentially "social identities." Identity has always been explored at an individual level, and with the passage of time its investigation has been extended to include activities at a group level (Puusa \& Tolvanen, 2006). This is mainly because identity cannot be viewed as separate from the social milieu in which it is located. Identity implies the ability of the individual to be aware of the different meanings that he/she associates with herself/himself and the meanings that others assign to him/her. This happens through interactions with others; hence identity is seen as both a process and a product of social interaction (Beauchamp \& Thomas, 2009). In this study the way one views oneself and is viewed by others, and wishes to be in future is their identity.

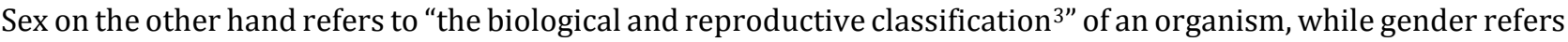
to "the cultural ${ }^{4}$ aspect of sex" (Franklin, 2012, p. 1; Scantlebury \& Baker, 2007, p. 258). According to Schmitt, Leclerc, and Dubé-Rioux (1981, p. 122) gender serves as an important social category in all cultures, because each culture develops a "rich network of associations that surround its concepts of maleness and femaleness."

\footnotetext{
3 Male or Female

${ }^{4}$ In other words, how we come to know ourselves as social human beings that are male and female (Franklin, 2012, p. 1; p. 2)
} 
However, "individuals within a culture may differ from one another in the degree to which they utilise cultural definitions of masculinity and femininity as standards against which they perceive, categorise, and evaluate gender-related [roles and] information" (Schmitt et al., 1981, p. 122). In other words, gender is "a way in which social practice is ordered." (Connell, 2005, p. 1804).

Our "socialisation into gender appropriate roles begins when our sex is identified5" (Franklin, 2012, p. 5). Even before birth, parents "invest in gender appropriate toys for their unborn babies" (Franklin, 2012, p. 36). For example, "infants' bedrooms are decorated differently reinforcing gender differences" (ibid, p. 31) and their toys are stereotyped from a very early age. Hence, gender is probably one of the very first influences on identity, thus, Gender Development Theories (GDT) are explored in some detail in the sections below.

\subsection{Gender development theories (GDT)}

A number of GDT are described in literature (Franklin, 2012; Lips, 2008), however, for the purposes of this study, two theories, that is Social Cognitive Theory (SCT) and the Gender Schematic Theory (GST) are considered. I chose these two theories because their focus is directly related to how one views oneself in relation to gender and how that might result in different perspectives based on gender. These two theories link directly to the Feminist Standpoint Theory (FST which serves as one of the theoretical lenses that informs this study.

One element of concern that needs noting is that theorising about gender has been predominantly a Eurocentric occupation (Dawes \& Biersteker, 2011) with very little recorded information from an African perspective. Dawes and Biersteker (2011) in a chapter on early childhood development in the Handbook of African Generative Curriculum confirm much of what is described in SCT and GST with respect to identity in an African context. In this respect, one of the outcomes of this study might be a contribution to the body of knowledge that relates to the influence of identity and identity formation in an African context.

\subsection{Social cognitive theory (SCT)}

Human learning is "cognitively mediated" (Lips, 2008, p. 190). SCT conceptualises gender development and functioning as the product of the interplay between cognitive, affective, biological, and socio-structural influences. It argues for the influential effect of cognitive factors (thinking and memory) in self-development, adaptation, and change. Hence, it adopts "a multifaceted social construction model of gender" (A Bandura \& K Bussey, 2004, p. 679) where both mental activities (cognitive) as well as family or peers have an influence on shaping gender identity.

When informed about a child's biological sex, parents and others in the community often relate to the child based on the gender-role expected of the child (Lips, 2008). According to SCT, children are encouraged or coerced to fit in with social expectations provided by their societies (Lips, 2008). This is one reason why boys and girls learn to behave differently since they are treated differently by their parents and their communities. SCT emphasises the power of observational learning and reinforcement. Bandura (1977) as cited by Lips (2008) suggests that the child develops gender identity through a learning process that involves imitation, modelling, and reinforcement. The theory rests on the assumption that boys learn to be masculine and girls learn to be feminine because genderrole appropriate behaviour is rewarded and gender-role inappropriate behaviour is punished or ignored. Children learn which behaviours are gender-role appropriate by observing and imitating adults and peers and through trial and error. In SCT, peers function as one of the inter-dependent societal subsystems that contribute to gender differentiation. However, it must be noted that peers are not the initiating motivators or the originators of gender development (Albert Bandura \& Kay Bussey, 2004).

"Gender labelling assumes special significance in early gender development because it gives salience to sorting people on the basis of gender, aggregates the features and activities that characterise each gender, and provides the basis for categorising oneself" (Bandura \& Bussey, 2004, p. 680). Once gender self-categorisation occurs, it takes on added significance as children increasingly recognise that the social world around them, composed of institutional arrangements, norms, incentive systems, environmental supports, constraints and opportunities, is heavily structured around this categorical differentiation (ibid.). While SCT adds the dimension of imitation and modelling, it is gender schemas used by the children that regulate their behaviour to achieve culturally acceptable notions of femininity and masculinity.

\subsection{Gender schematic theory (GST)}

Gender Schematic Theory and SCT are interrelated. SCT portrays the child as both actively constructing gender

${ }^{5}$ Prenatally or at the moment of birth 
categories and responding to environmental cues while GST is based on the idea that children form organised knowledge structures $\left(s c h e m a s^{6}\right)$, which are gender-related conceptions of themselves and others. These schemas influence children's thinking and behaviour (Carol Lynn Martin \& Diane Ruble, 2004). GST begins with the observation that the developing child invariably learns his or her society's cultural definitions of "femaleness and maleness" (Bem, 1983, p. 603). It proposes that, in addition to learning content-specific information about gender, the child also learns to invoke a heterogeneous network of sex-related associations in order to evaluate and assimilate new information (ibid.). The child, in short, learns to "encode and to organise information" in terms of an evolving gender schema, that is, a network of associations that organises and guides an individual's perception (S. L. Bem, 1983, p. 603). This may include general expectations about people, social roles, and events and how to behave in certain situations. GST thus construes perception as a constructive process in which the interaction between incoming information and an individual's pre-existing schema determines or influences what is perceived.

It is crucial to understand that these "schemas and stereotypes are a by-product of that particular environment," (Franklin, 2012, p. 102). Campbell, Shirley, and Candy (2004) claim that the acquisition of gender schemas begins during infancy. This acquisition of gender schemas occurs in three stages which according to Franklin (2012, p. 103) are:

1. Beginning of awareness - children of between 2 and 3 years develop gender schemas.

2. Rigidity - between five to seven years, the knowledge is organised into very strict gender schemas with no flexibility, for example, 'only girls can wear pink'.

3. Flexibility - which occurs around seven years of age for example, children learn to realise that boys can wear pink.

It is during these three stages that gender schemas become integrated into cognitive models. Franklin (2012, p. 103) further explains that "once these gender schemas have become internalised, the child begins to use these as a marker for their own behaviour." Girls develop aspects of how they should behave. Bem therefore argues that: "The gender schema becomes a prescriptive standard or a guide and self-esteem becomes its hostage. Here, then enters an internalised motivational factor that prompts an individual to regulate his or her behaviour to that which conforms to the cultural definition of femaleness and maleness" ((D. ). Bem, 1983), p. 605).

It is becoming evident that the gender schemas are used by the child (female student) to "regulate their behaviour to achieve culturally acceptable notions of femininity" (Franklin, 2012, p. 104). Franklin claims that GST proposes that individuals are schematic (i.e. conforms strongly to gender schemas) or aschematic (i.e. are not concerned with gender schemas). However, it must be noted that it would probably be very difficult to raise children in an aschematic way in a schematic society. This is because there are a number of set assumptions in any given society and these assumptions affect how we perceive gender in daily interactions and events. The next section deals with the theoretical perspectives.

\subsection{Theoretical perspective}

One of the theories that I used was the Feminist Standpoint Theory (FST) which serves as one of the theoretical lenses that informs this study. The premise of Feminist Standpoint Theory is that it is the difference in the social experiences of men and women that give them different ways of looking at life and interpreting events and hence different standpoints. However, Smith (1987) notes that science is developed primarily from the perspective of one group, namely, a male Eurocentric view. Hence, I used the FST to select the female students doing physics who have a different stand point from that of males.

Considering the various socio-cultural and gender-related factors that influence identity, it becomes apparent that the shaping of identity largely occurs in learning communities. Therefore, Wenger's Social Learning Theory (SLT) was also used. This framework was used as an analytical toolkit in this study to elucidate the meanings within the diagrams of female students, with the aim of showing the female students' images of scientists.

Wenger's SLT is built on four assumptions about what matters in learning and these are: humans are social beings and this assumption is a central aspect of learning; that knowledge is a matter of competence with respect to valued enterprises; knowing is a matter of active engagement in the world; and meaning is our ability to experience the world and to engage with it in a meaningful way ((Etienne Wenger, 1998), p. 4). These four assumptions conceptualise learning as an inter-play of four components mediated by social participation, namely: meaning (learning as experience), practice (learning as doing), community (learning as belonging) and identity (learning as becoming) (Etienne Wenger, 1998). SLT was used as a lens to interpret the behaviour of female

\footnotetext{
${ }^{6} \mathrm{~A}$ schema is a mental structure or cognitive repertoire, which contains general expectation and knowledge of the world.
} 
students in a learning environment and their attempts to author their identities in a CoP. Smit and Fritz (2008) argue that meaning is central to human behaviour in the sense that humans act toward people and things based on the meaning that they have attributed to those people or things. Learning in Wenger's SLT is viewed as social participation and the development of one's identity is closely integrated with the learning that takes place as a result of one's participation in a CoP. Therefore, issues of identity are difficult to separate from those of learning. Lave and Wenger (1991, p. 13) argue that from a social perspective, learning should be conceived of as "a process of social participation rather than a matter of acquisition of knowledge and cognitive skills in the head" and therefore is intrinsically linked to the construction of identities.

\subsection{Data and methodologies}

The qualitative narrative research design, used in this study, situated me in the world of the participants (N. K. Denzin \& Y. Lincoln, 2000)(N. K. Denzin \& Y. Lincoln, 2000)(N. K. Denzin \& Y. Lincoln, 2000)(N. K. Denzin \& Y. Lincoln, 2000)(N. K. Denzin \& Y. Lincoln, 2000)(N. K. Denzin \& Y. Lincoln, 2000)(N. K. Denzin \& Y. Lincoln, 2000)(N. K. Denzin \& Y. Lincoln, 2000)(N. K. Denzin \& Y. Lincoln, 2000)(N. K. Denzin \& Y. Lincoln, 2000) and, hence, according to Babbie and Mouton (2001), the research process took an insider perspective. Qualitative researchers according to Denzin and Lincoln (2003, p. 13) are guided by a set of principles that emphasise the "socially constructed nature of reality, the personal relationship between the researcher and what is being inquired, and the situational constraints that shape the inquiry." Qualitative inquiry is, therefore, a method of investigation that is "systematic and interactive," and is employed to give an exposition of the life experiences of the participants and also to give meaning to these experiences (Mouton, 2002, p. 161). As such this method grounded in an interpretive paradigm enables one to gain an in-depth understanding of the human perspectives at the individual level.

\subsection{Sample and context}

Three schools were purposively selected for the study. Two were co-education government schools categorised as low and high density schools based on the social and economic standards of the communities in which the schools are situated. The third school was an all-girls non-government school categorised as a low density school. Low density schools are generally well resourced with adequate laboratory facilities (three laboratories for senior and two for the junior students) and well-qualified science teachers. Generally, high density schools are not well resourced, having only two laboratories, one for the senior and one for the junior students.

I purposively selected three schools which I assumed had the appropriate data I wanted (Creswell, 2013). The participants were drawn from a population of A-level female science students at these selected schools. Female adolescents aged 18years and above doing Advanced Level (A-level) in lower 6 (form 5) or in upper 6 (form 6 ) were chosen as the participants of this study. A sampling questionnaire was designed and self-administered to all female students doing A-level sciences. This served to purposively identify participants who met the inclusion criterion of age limit of eighteen years and above. The inclusion criteria also considered participants whose subjects were mathematics with physics and physics only without mathematics.

Based on the criteria employed in the purposive sampling, I chose four students to participate in the study. From the low density school, one female student doing mathematics and physics was selected. Two female students were chosen from the high density urban school, one doing physics and mathematics and the other doing physics without mathematics. Traditionally, students at A-level enrol for both physics and mathematics as a combination of subjects to pursue a career in physics or in engineering. Her inclusion therefore would enrich the generated data. One student from the low density all-girls school doing mathematics and physics was also selected. Table 1 below summarises the participants of the study.

Table 1: Participants of the study

\begin{tabular}{|c|c|c|}
\hline School context & Code of students & Subjects \\
\hline $\begin{array}{l}\text { Low Density Schools } \\
\text { - } \quad \text { Educated community } \\
\text { - } \quad \text { Well-resourced } \\
\text { - } 5 \text { laboratories ( } 3 \text { for seniors and } 2 \text { for juniors) } \\
\text { NB: Only } 2 \text { females out } 20 \text { male students doing physics }\end{array}$ & S1 & $\begin{array}{l}\text { Mathematics } \\
\text { and Physics }\end{array}$ \\
\hline $\begin{array}{l}\text { High Density Schools } \\
\text { - Most people not educated } \\
\text { - Not well-resourced } \\
\text { - Two laboratories only ( } 1 \text { for seniors and } 1 \text { for juniors }\end{array}$ & $\begin{array}{l}\text { S2 } \\
\text { S3 }\end{array}$ & $\begin{array}{l}\text { Mathematics } \\
\text { and Physics }\end{array}$ \\
\hline
\end{tabular}


NB: S2 were only 2 females out 18 male students doing physics in her class

S3 was the only female out 16 male students doing physics

Low Density School (All-Girls)

- Educated community

- Well-resourced

- 5 laboratories (3 for seniors and 3 for juniors)

NB: There we 25 females doing physics and 107 females doing only maths
Physics, no

Mathematics

S8

Mathematics

and Physics

\subsection{Research instruments}

The techniques of generation were semi-structured interviews which were audio taped, Draw- A-Scientist (DAST) and classroom observations (which were videotaped). The observations were carried out to reveal the interaction patterns displayed when the female students were doing theory and practical lessons in their physics CoP.

\subsubsection{Classroom observation guide}

Observation is a systematic process of recording the behaviour and patterns of participation without necessarily questioning or communicating with the participants (Nieuwenhuis, 2007). The author explains further that it is a naturalistic technique in the interpretive paradigm where female students were observed in their natural environment. Observation is an everyday activity where senses (seeing, hearing, touching, smelling and tasting) are used to generate data (ibid.). As a qualitative data generating technique, observation is used to enable the researcher to gain a deeper understanding of the phenomenon being observed (Nieuwenhuis, 2007). The risk is that observation by its very nature is highly selective and subjective since researchers focus on specific events or objects within the whole thereby cutting them off from the whole (Creswell, 2007; Nieuwenhuis, 2007). The risk of observation was minimised by formulating an observational schedule which was then used during the data generation process.

Female students were observed doing their theory and practical lessons in physics. These lessons were videotaped to enable me to extract the participation and interaction patterns (teacher-pupil and pupil-pupil). Observation provided me with an insider perspective of the group dynamics and behaviours in different settings. Observation allowed me to hear, see, to begin to experience (observation) and reflect on (which is part of the interim data analysis) how setting is socially constructed in terms of "power, communication lines, discourse and language" (Nieuwenhuis, 2007, p. 84). A total of three theories and three practical lessons were observed, one of each from the schools that were offering physics as a subject.

\subsubsection{Drawing some of the main highlights of their life which they could relate to their aspirations to study physics}

Visual data have become a prominent approach in qualitative research in general and qualitative researchers are now using images to enhance their understanding of the human condition (Knoblauch, Baer, Laurier, Petschke, \& Schnettler, 2008). The use of visual data encompasses a wide range of visual forms, including films, videos, photographs, drawing, cartoons, graffiti, maps, diagrams, cyber graphics, signs and symbols (Weber, 2005). The visual images present a powerful collection of techniques to access and gain insight into people's lives and environments. Drawing can be used as a form of expression, reflection and therapy (Stuart, 2007). They allow for the communication of both physical and emotional worlds and can "promote social action contributing to social change" (Galvaan, 2007, p. 153). Use of drawings within visual methodologies is economical, requiring minimal supplies and it is highly generative and provides rich data. It also encourages free imagination (Barnes \& Kelly, 2007). Mitchell, Theron, Smith, and Stuart (2011, p. 230) argue that they like drawings as a method because of "their simplicity (need paper and pencil or pen) and their tangibility, their concreteness take us inside the mind of the participants." Drawing can be used as a tool to access perceptions and thus prove useful in addressing identity related issues in a number of ways. But perceptions, as we know, can change, and changing perceptions can bring about changes in the behaviour of individuals and groups in society (Stuart, 2007). Drawings can communicate complex messages in simple but rich ways. They are "lasting artefacts that can be used to give voice to participants' messages" (Mitchell et al., 2011, p. 5), making it a suitable method to my study.

Mitchell et al., (2011) believe that the use of drawing is also appropriate for getting at the memories, thoughts and feeling of students. Despite the fact that drawings have "procedural, ethnical and interpretive challenges, these cannot corrode the rich persuasive evidence embedded in the apparent simplicity of drawings" (Mitchell et al., 
2011, p. 5). The female participants in this study were asked to draw some of the main highlights of their lives which they could relate to their aspirations to study physics. The justification for this was to gain an insight into the origins of their expressed interest in physics since the data gathered may possibly provide some clues towards the female students' natural enthusiasm towards science (Bodzin \& Gehringer, 2001). This was followed by 'Tell me about your picture (s)' (Mitchell et al., 2011, p. 5). A discussion of what the drawing means and clarification or explanation, often propelled further relevant data generation. This shared analysis encouraged richer, researcher understanding of the phenomenon in question (Mitchell et al., 2011). Drawings, therefore, enabled the four female students doing physics not only to access their experiences but also to reveal these experiences and perspectives to others. The female students explored their perceptions as well as experiences of themselves towards physics and explained how their perceptions influenced their participation in physics. The Draw-AScientist Test is considered next.

\subsubsection{Draw-A-Scientist test}

The Draw-A-Scientist Test (DAST) has been widely used for decades to examine, analyse, and evaluate students' and teachers' perceptions of scientists(Kevin D Finson, 2002)(Kevin D Finson, 2002)(Kevin D Finson, 2002) (Kevin D Finson, 2002; Pedersen \& Finson, 2009)). All the female participants studying physics were asked to draw a picture of an imaginary scientist based on the model of Draw-A-Scientist Test (DAST) suggested by Chambers (1983). The rationale for using DAST was to explore female students' mental images of scientists in an effort to discern their perceptions towards science in general and physics in particular. They were asked to provide a name, age, nationality and gender for the scientist they had drawn. One of the research questions of my study was to find how female students' perceptions of physics influenced their participation in the subject, making DAST relevant to my study.

The female participants were also asked to write the names of other scientists they knew or had heard of (Weber, 2005). The purpose was to find out whether these students perceived scientists as ordinary people who are involved in the world around them or in their societies, for example, laboratory technicians, nurses, doctors etc. or only as famous ground-breaking people they encounter in their science text books.

\subsubsection{Techniques used to find common themes}

Babbie (2001) defines content analysis or thematic analysis as "the study of recorded human communications." It is a method for "identifying, analysing and reporting patterns (themes) within data" (Braun \& Clarke, 2006, p. 79). According to Riley and Hawe (2005), thematic analysis may be done in two ways; either themes are generated deductively by the researcher's a priori interests or inductively deriving them from the data itself i.e. the open coding of data by looking for patterns in the data or the building of a set of themes to describe a phenomenon. Emphasis, according to Riessman (2006, p. 186), should be put on the content of the text, that is on the "what" is said rather than the "how" it is said. The thematic analyses should reflect both the ideas researchers bring to the data set beforehand (from the research questions) as well as being open to 'new' themes in the data. Y. Zhang and B. M. Wildemuth (2009) argue that sometimes a compromise between the two methods of generating the themes is possible and this is what I did in this study. As I made a compromise between inductive and deductive approaches, I was guided by Ryan and Bernard (2003,p. 94) who cautioned that on one hand, a strict theoretical perspective may lead the researcher "to find only what they are looking for" while on the other hand "assiduous theory avoidance... brings the risk of not making the connections between the data and important research questions." Finding common elements across the participants' stories is important because it can be useful in elaborating a developing theory.

From the interpretive perspective, making explicit the techniques I used for discovering themes is important because without thematic categories, investigators have "nothing to describe, nothing to compare, and nothing to explain" (Ryan \& Bernard 2003, p. 86) and it allows consumers of qualitative data to assess methodological choices. Being guided by Ryan and Bernard (2003, pp. 88-93) and Love (1994, p. 2), I extracted techniques that I used to identify common themes across the four female participants:

- Repetitions: This was the easiest way because I was looking for topics or elements that recurred in their stories.

- Similarities and differences: These are usually found by making a systematic search for them across units of data beginning either with a line-by-line analysis and asking questions such as, what is this sentence about? How is it similar to or different from the preceding or following statements? This kept me focused on the data rather than on theoretical aspects. I also compared either pairs of expressions or pairs of whole text for similarities and differences and asking, how is one expression different from or similar to the other? The abstract similarities and differences that this question generated were the themes.

- Historical explanations, descriptions and interpretations: These were stories of the past that were used to explain and justify present behaviours as well as meaning. 
I used these techniques to search for themes from the data. This process of qualitative content or thematic analysis began during the early stages of data generation phase and it helped me to move back and forth between concept development and data generation and helped me to direct subsequent data generation towards addressing the research questions (Miles \& Huberman, 1994). Although it is common practice to use typical quotations to justify conclusions (Schilling, 2006), I strove for a balance between description and interpretation (Y. Zhang \& B. Wildemuth, 2009). As mentioned earlier, qualitative research is fundamentally interpretive, and interpretation represents my personal and theoretical understanding of the phenomenon under study.

\subsection{Results and discussion}

The data on the classroom and laboratory experience is presented first and then the data on the Draw-A-Scientist Test.

\subsection{Classroom and laboratory experience}

The data gathered from classroom observation indicate that the 0 ' and A-level physics classrooms/laboratory environments of female students doing physics were conducive for learning in a CoP. This is because female students were encouraged to ask questions, read more, take apparatus first before distributing to male students and the male students were asked to share when there is a shortage of equipment. They were also urged to work harder and this, in a way may have aided these female students to construct a positive physics identity. However, asking them to read more and to work harder may indicate the teacher's perception that the female students were not intelligent enough to study physics. During classroom observation, when students were being taught one theory lesson and one practical work, I observed that the teacher had more or less same interaction time with both male and female students. They treated the male and female students equally well without showing any favouritism with the exception of the S3 teacher. All the students were asked to find information on given topics so that they could come to present to the whole class. There was good rapport between the female students doing physics and their teachers. There was teacher-student as well as student-student interaction in this physics community. The teachers were asking thought-provoking high order questions. What must be known is that physics is a social construct which is informed by students' lived experiences and social interaction as mentioned previously. As students develop knowledge and competence and meaning from these interactions, they begin to construct their identities in terms of who they wish to be in relation to their communities. Hence, one's selfconcept shapes one's attitude to physics and is a predictor of students' decisions to continue to study physics.

The female participants were observed during the practical and theory lessons. Specific examples of S1, S2, S3 and S8 that I observed by way of the interaction between these students and their teachers are worth noting. For example, the male physics teacher of S1 reprimanded male students for laughing at female students during lessons. S1 always took a seat in front of the class and during the theory lesson she remained in the laboratory to ask the teacher pertinent questions. She was competing well with male students in terms of tests. This female student was comfortable in handling apparatus and was also very comfortable both in the laboratory and in the classroom. She actively participated in both theory and practical experiments. S1 voluntarily paired with a male student and not with the other female student as they were doing the practical experiment in pairs demonstrating shared practice in a CoP. They were investigating how the motion of a pendulum bob is affected by the height above the bench. She was actually doing the experiment and the male partner was recording the time the bob took for each complete swing. There was an enabling classroom environment with respect to resources and promoting learning in CoP. S1 had gone against the cultural norm by opting to study physics. She came from a family of four brothers and four cousins who had all done physics and were engineers by profession. S1's voluntary pairing with a male student may indicate that the rapport between the two students was good and that she was confident and courageously creating an identity for herself.

S2 was competing well with male students in terms of tests and class exercises. As was the case with S1, she also paired with a male student and not with the other female student during the practical work. S2 had stated during interviews that she was excited to be in a male dominated classroom. This may suggest that she was interacting well with the male students and that she was determined and confidently creating a physics identity for herself as well. They were investigating the extension of springs supporting a load as the load was varied. They ended by drawing a graph individually as was required in presenting the data collected during the experimental activity. The whole group was working well. All the students were able to complete their task within the given time. During the theory lesson, S2 made a presentation to the whole group on electro-magnetic induction demonstrating understanding and meaning making. She was very confident in explaining to the whole class the factors that affect electromagnetic induction. It shows that the opportunities and support provided by the male physics teachers of S1 and S2 resulted in these female students gaining confidence and taking a leadership role to become active participants in the learning community. 
S3 always took a seat in front of the class. She was comfortable handling the apparatus when they were carrying out the experiments in the laboratory. Because the teacher had requested that they work in pairs showing shared practice in a CoP. S3 had no option but to pair with a male student since she was the only female in that class. These were the male students who were subjecting her to immense peer pressure. As outlined in the previous sections, S3 used to ask questions but of late she was no longer comfortable asking questions during lessons. This was because of the behaviour of male students toward her, in particular, the comments they passed during the lessons and during their study period, which implied that she was inferior compared to them. She wrote her questions down and would then ask the teacher later or ask other female students who were in the final year of A-level. S3 usually performed better than male students in class tests, demonstrating that she was exerting a lot of pressure on the male students by outperforming them as she was constructing a positive physics identity for herself in this CoP.

S8 on the other hand was learning at an all-girls school. This school was well resourced and as a result, the female students did not work in pairs but carried out the experiments individually in the laboratory. The male physics teacher was creating an enabling classroom or laboratory environment where female students were expressing their identity during classroom engagements. The teacher of S8 had more or less the same interaction time with all the female students; S8 was competing very well with other female students doing physics in terms of performance in tests.

Although the teacher of S3 could not fully control the behaviour of male students, he did, however, try to give her support as a student who was studying physics without mathematics. He made sure that S3 participated in class as she came from a different level. Opportunities and support were also provided by the male physics teachers of $\mathrm{S} 1, \mathrm{~S} 2, \mathrm{~S} 3$ and S8. This caused them to gain confidence to participate in a physics CoP.

As has been explained above, when I observed S1, S2, S3 and S8 in the laboratories doing practical and theory work, I noted that they engaged or participated fully and effectively in learning physics within an enabling CoP. This is in line with Murphy and Whitelegg (2006) who explained that social theories of learning emphasise that learning occurs as individuals engage in and contribute to the practices of their communities. From this perspective, physics classrooms can be understood as communities of learners. Female participants must be able to engage mutually with the other participants to feel a sense of belonging or membership (Wenger 1998). To engage, they have to draw on what they do and what they know.

Generally, the teachers provided these female students with an opportunity to express and evolve their identities by helping them to actively participate in practical and theory work. The female students were all very confident in carrying out practical work and in presenting the assigned topic to the other students in a class, without any stage fright. They belonged to a CoP where they were participating fully as members. According to Wenger (2010), there is a profound connection between identity and practice. Developing a practice requires the formation of a community whose members can engage with one another and thus, acknowledge each other as participants. As a consequence, practice entails the negotiation of ways of being a person in that context. The formation of a community of practice is also the negotiation of identities (ibid.). Identity in this case can be defined as negotiated experience. We define who we are by the way we experience ourselves through participation as well as by the ways we and others reify ourselves (Wenger (2010)). Identity includes not only our knowledge and experiences, but also our perceptions of ourselves, ${ }^{7}$ others' perceptions of us, and our perceptions of others' perceptions of us that develop as we participate in communities with one another (Van Zoest \& Bohl 2008). As such, our identities do not exist only within ourselves, but rather are strung between us and the others with whom we interact. In a sense, then, our identities (Van Zoest \& Bohl 2008) are the "vehicles from within which we participate with others in community - vehicles that provide both potentials for and limitations to our participation, and that are modified as we learn and grow through mutual participation in joint enterprises with others." Thus, a person's own and others' perceptions of his/her location and trajectory within a community are key aspects of that person's identity in practice. Therefore, it is from observing others in a CoP that one forms an idea of how new behaviour should be performed and later this coded information serves as a guide for action in their communities of practice (CoPs). The author stresses that students are active participants and learners in many different CoPs, in which they have formal and informal apprenticeship opportunities to learn the common language, conventions, rituals, stories and histories valued within each community.

E Wenger (1998) explains that participation in collaborative activities is closely intertwined with reification and that reifications are representations of practice which give form to experience and provide a focus for participation. This implies that meaning grows out of an interweaving of participation and reification and that without participation and practice, reifications are abstract and inert. Practice without reification leaves little to

\footnotetext{
7 i.e. our values, beliefs, desires, motivations, and self-identifications
} 
reflect upon. Physics identities therefore require negotiation and construction as female students engage positively with traditionally masculine areas of study after having developed the confidence to relate to and meaningfully interact with male peers during mutual engagement as was demonstrated when these students' behaviour was observed during classroom engagement.

In brief, identity is a powerful construct for understanding student learning because identities are constructed through practice. The female students' experiences determine the way they form their identities, behave in class, interact within the group and with the teacher and the way they interpret the knowledge presented. This means that the schema which individuals develop about the process of identity formation might be a product of selfconstruction as well as social construction. The way female students are socialised affects the way they interact within their communities of practice and hence the way they form their identities. Prusak (2003) argued that sociocultural context affects individual learning; hence in the case of this study it may directly affect the participation of female students in physics.

\subsection{Drawing a scientist}

All the female participants studying physics (S1, S2, S3 and S8) were asked to draw a picture of an imaginary scientist based on the model of Draw-A-Scientist Test (DAST) suggested by Chambers (1983). The rationale for using DAST was to explore female students' mental images of scientists in an effort to discern their perceptions towards science in general and physics in particular. They were asked to provide a name, age, nationality and gender for the scientist they had drawn. In addition, the female students were also asked to write the names of a few other scientists. The purpose was to find out whether these students perceived scientists as ordinary people who are involved in the world around them or in their societies, for example, laboratory technicians, nurses, doctors etc. or only as famous ground-breaking people they encounter in their science text books (see other sections of the thesis). Finally, the female participants were asked to draw some of the main highlights of their life which they could relate to their aspirations to study physics. The justification for this was to gain an insight into the origins of their expressed interest in physics since the data gathered may possibly provide some clues towards the female students' natural enthusiasm towards science (Bodzin \& Gehringer, 2001).

A preliminary analysis of the diagrams drawn by the four students and subsequent discussions with them showed that S1 and S2 had similar conceptions of a scientist, i.e. a scientist as a male from a Eurocentric background while S2 and S3 visualised a scientist to be a female in an African cultural setting. Therefore, the analysis of the diagrams drawn for a scientist and related activities of S1 and S2 are presented first before discussing the data for the same activities gathered from S2 and S3. The diagrams drawn by the different students are shown below.

The scientist drawn by S1 was given the names of two physicists, namely, Albert Einstein and Isaac Newton as indicated in Fig 1 above. During the interview she was asked to explain why she gave two names to one diagram. Her response was that the two names of these two scientists came to her mind first and she wrote them down before doing the drawing. S1 was also familiar with Newton's first law of motion as she wrote it alongside her diagram as indicated in Figure 1. Newton's laws are not taught at A-level and it seems that it was learnt by rote from a science text book when doing O-level physics. This seems to indicate that her O-level experience might have had a positive influence on her decision to study physics. She further described the scientist as having a funny hairstyle, mature (over 50 years old) and that he might not have been happy as he was by himself carrying out experiments in a laboratory. Albert Einstein was correctly described as a male American physicist who was born in Germany. She added that due to the nature of their work, for example using microscopes, scientists may suffer from eye strain necessitating the wearing of spectacles.

The second participant (S2) also drew a male scientist, Mendeleev as shown in Figure 2 below. The scientist named by $\mathrm{S} 2$ was not a physicist but a chemist who was famous for the invention of the periodic table which is not taught at Alevel as well. This suggests that S2 also might have been influenced by her O-level science experience.

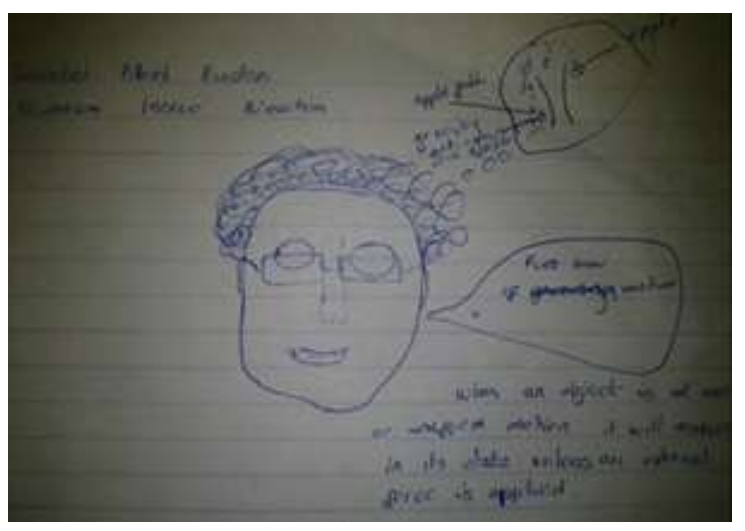

Figure 1: The scientist drawn by S1

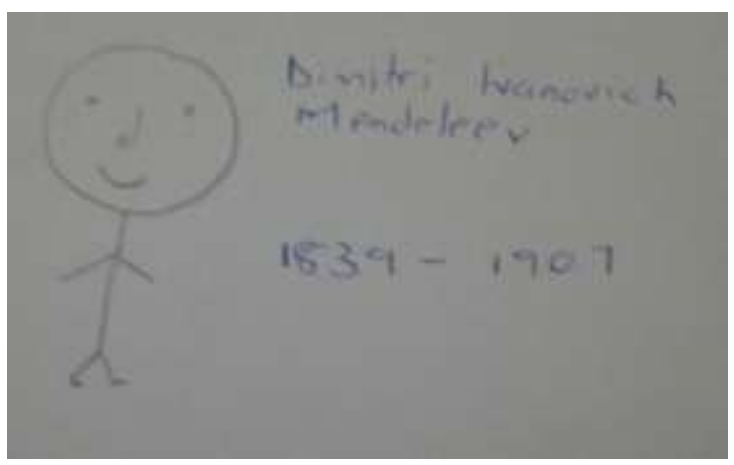

Figure 2: Scientist drawn by S2 
S2 stated that the scientist she had drawn was a Russian male who was 49 years old. During interviews she further described that scientists always worked as individuals in a laboratory.

S1 listed other scientists as shown in Fig 3 below. The seven scientists that she named were all male physicists except for Mendel, Raoult and Bunsen.

Similarly, S2 also listed mostly male physicists as shown in Figure 4 despite having drawn the image of a scientist who was a chemist.

S1 and S2, as outlined above, gave male names to their drawn scientists and their choice of listed male names from a European background (figures 3 and 4 respectively) seemed to indicate that they had a stereotype male image of scientists who are usually depicted in their text books. As Türkmen (2008) suggests, the image of a scientist among students is affected by male physics teachers and science textbooks. S1 and S2's perceptions of scientists are in line with Paechter (2003) who found that most female students attribute a masculine perspective to physics which could have its origins in the cultural socialisation of females as suggested by McCullough (2004) and Farland-Smith (2009) which portray the perception that all scientists are males. Female students may be reluctant to participate (or engage) in science, especially physics, because they often perceive the identities of scientists as inconsistent with their own (Brotman \& Moore, 2008). This could lead to more female students excluding themselves from the physics educational and professional opportunities as a result of their low participation in the subject.

It is also worth noting that neither of the two students named a

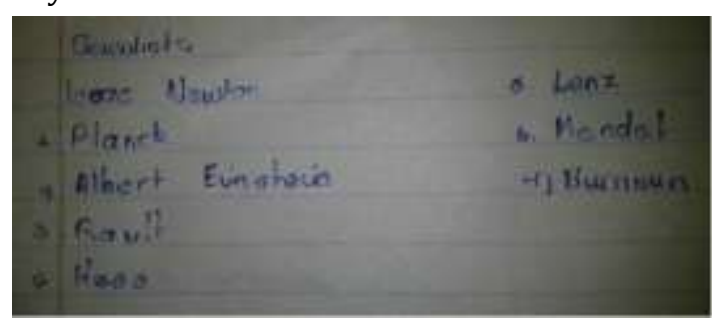

Figure 3: S1's list of scientists

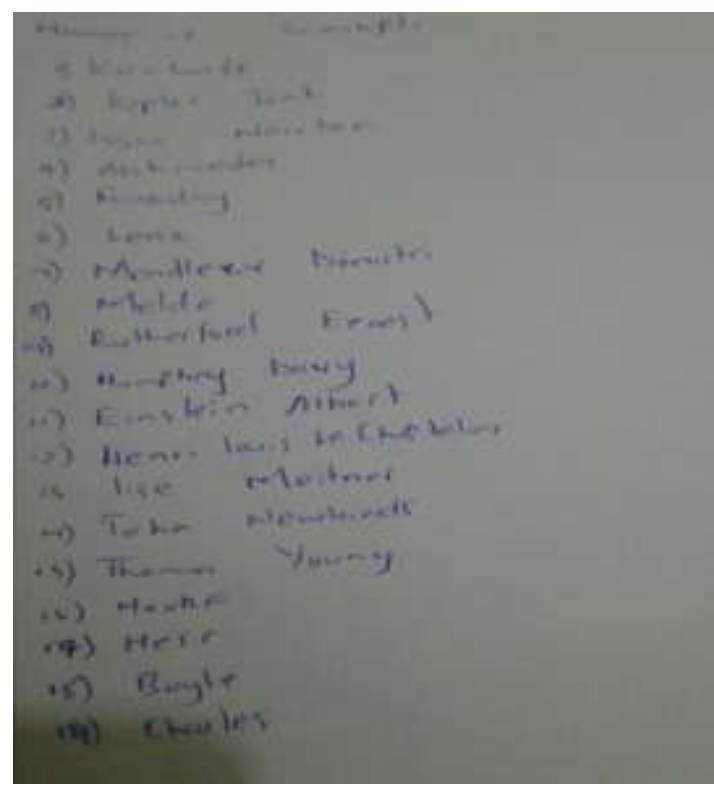

Figure 4: S2's list of scientists single female scientist although the pictures of female scientists, for example Marie Curie, are shown in some physics text books and discussed during science lessons. The listing of male scientists by S1 and S2 may suggest that, because female students' identities are socially constructed in relation to their classroom experience, their actions then become an expression of this social identity. From the ages they gave to the drawn scientists, both S1 and S2 seemed to hold the perception that scientists are mature people who always work in the laboratory. However, the female students did not seem to perceive scientists as ordinary people but as famous inventive people they encountered in their science text books.

Drawings often assist people in their journey back to recollect and represent highlights of their lived past experiences (Olivier, Wood, \& De Lange, 2007). Drawings are therefore an effective way of encouraging people to express what they are thinking, feeling, longing for or even their good or bad experiences. As mentioned earlier, the female students doing physics were asked to draw pictures of events in their lives that they would consider as important in developing an affinity for physics.
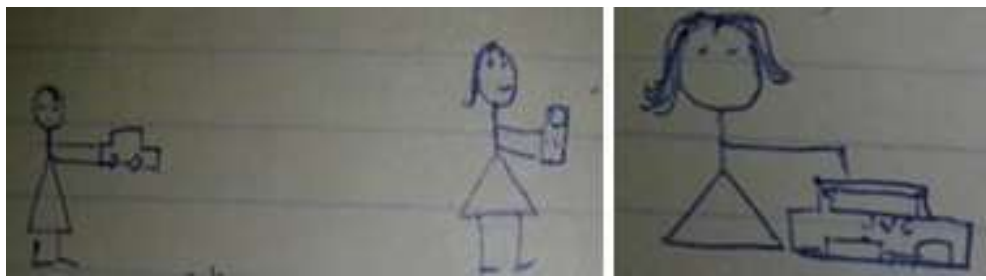

The following are the diagrams that S1 drew Figure 5: S1 playing with toy cars and cell phones showing herself playing with toy cars and toy cell phones (Figure 5). She refused to play with the dolls that her mother bought her. This may be due to the influence of male siblings, which eventually resulted in her choosing to study physics, thus creating an identity more attuned to a physics related career such as engineering.

The diagrams that $\mathrm{S} 2$ drew of the main highlights of her life that could be related to her aspirations to study physics are shown in Figure 6.

S2 indicated to me during the interview that she wished to become a medical doctor from as early as grade three. She chose physics, which is a requirement, in order to enable her to pursue studies in medicine. As

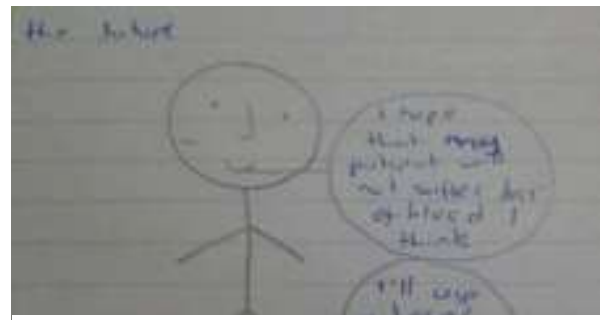

Figure 6: S2 imagining herself in the future 
shown in Figure 6, S2 imagined herself practising as a doctor, using a laser to cut a growth from the skin of her patient as illustrated above. A lot of physics is applied in the use of this device. Laser (an acronym for light amplification by stimulated emission) is a device that transforms various forms of energy into electromagnetic radiation. It emits narrow beams of intense electromagnetic radiation (light) based on the stimulated emission of photons and the principle behind the laser goes back to the world's most famous physicist, Albert Einstein, who in 1917 proposed a theory of stimulated light emission (Al-Azzawi, 2007). S2 described further that a laser can be used in information technology telecommunication, medicine, manufacturing, measurement and analysis, scientific research, metrology, microscopy etc. The use of the laser is an indication that S2 was aware that a lot of physics is involved in the construction and use of the laser in a variety of fields. This is a clear indication that she already started developing a physics identity which eventually influenced her to study physics.

The diagrams and lists of scientists provided by S3 and S8 are shown in Figures 7A and 7 B and figures 8A and 8B respectively. Both S3 and S8 drew female scientists and each provided an African name, specifically Zimbabwean names. The interesting point to note is that S3 drew herself as the scientist and wrote her name, aged 19 and of Zimbabwean nationality. During the interview, she identified herself as a physicist. This is significant because she perceived herself as a young African scientist implying that she was aware that scientists can also be very young.

On the other hand, S8 perceived a scientist to be mature because she stated the age 40 as shown in figure $7 \mathrm{~B}$. In the same figure above, S8 showed the scientist wearing a laboratory coat and corrective spectacles. This is significant that $\mathrm{S} 8$ seems to have paid more attention to personal safety equipment like the laboratory coat. A study conducted by Demirbas (2009) produced similar results in that students imagined scientists as wearing spectacles and a laboratory coat.

The names of scientists listed by both S3

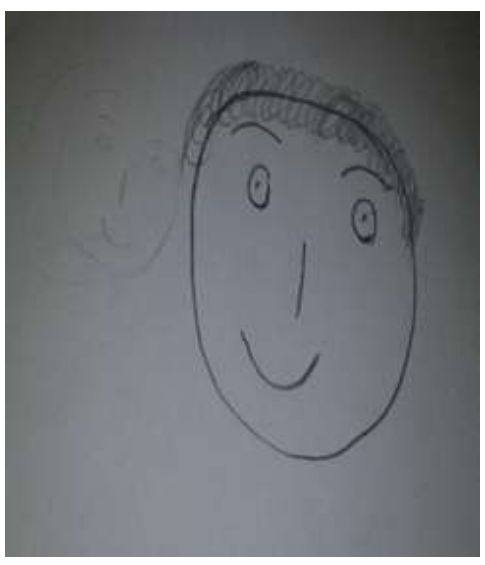

Figure 7A: S3's female scientist

and S8 are shown in figures $8 \mathrm{~A}$ and $8 \mathrm{~B}$ below. Both these female participants listed male and female scientists. S3 wrote her name first on the list of scientists (fig $8 \mathrm{~A}$ ) which I obliterated for ethical reasons. During the interview S3 said that she was an avid reader of the biographies of successful women in physics which indicates her interest in the subject and developing an identity for herself as a physicist. Furthermore, it points to the influence

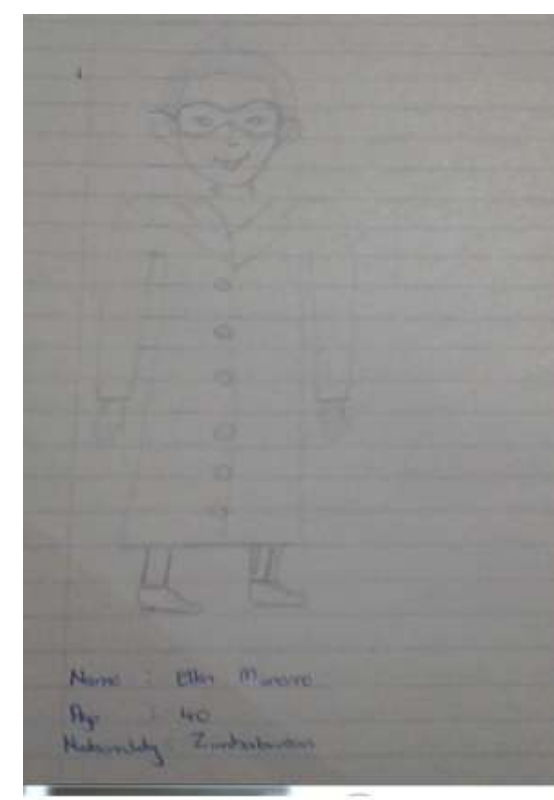

Figure 7B: S8's female scientist of female role models in shaping the identities of female students in their aspirations to become a scientist.

S8 was studying at an all-girls high school and this environment could have influenced her to include Marie Curie, a female physicist among her scientists. Although her physics teacher was a male, all her peers being females could have contributed towards her developing a self-concept that females are intelligent and are able to achieve success in physics. The list of scientists that S8 provided (Figure $8 \mathrm{~B}$ ) consisted mostly of physicists similar to the list supplied by S3. This seems to indicate that both S3 and S8, though studying in different school settings, had developed positive perceptions of physics.

The lists written by both S3 and S8 are significant in the sense that both these students seemed to be aware that scientists can

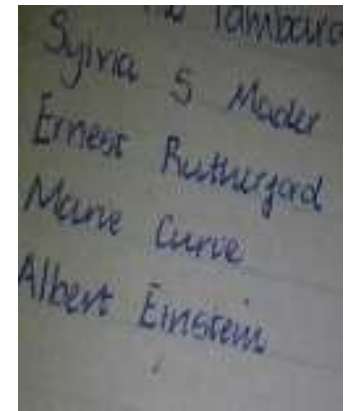

Figure 8A: S3's list of other scientists either be male or female, despite the prevailing cultural perception that scientists are males. The list of scientists supplied by S3 and S8 may indicate a Eurocentric perception of a scientist. However, their drawings of African female scientists appear to suggest that they also had an Afrocentric perception of a scientist. This was important because

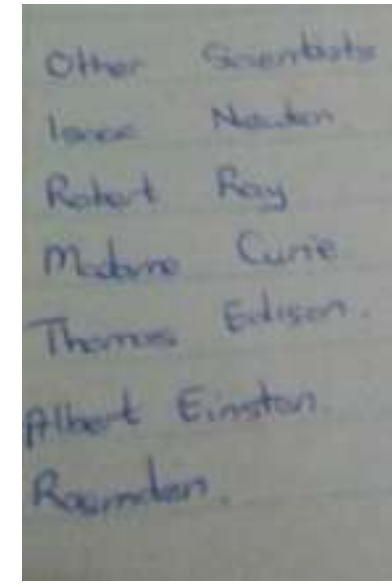

Figure 8B: S8's lists of other scientists neither perceived a scientist to be only Eurocentric as was the case with S1 and S2.

Figures 9 A and 9 B show some of the main highlights of S3 and S8's lives which they could relate to their aspirations to study physics. S3 explained that she foresaw herself being awarded a certificate of merit in physics at the university. This implies that she was determined to pursue a career in physics, suggesting that nothing 
would prevent her from achieving her goals. S8 drew her experiences when she was at a family party as illustrated in figure 9 B. During interview S8 said that when she was at a family gathering, a glass bowl was overloaded with fruits as shown by figure $9 \mathrm{~B}$. She was doing 0 level at the time and wondered why the bowl fell off. She could apply the principles of physics related to the centre of mass she learnt at Alevel to explain why the structure had no balance and caused it to fall over. She seemed to link physics to daily life, demonstrating her interest in studying the subject. This might imply that S8's passion might have developed a natural enthusiasm towards science.

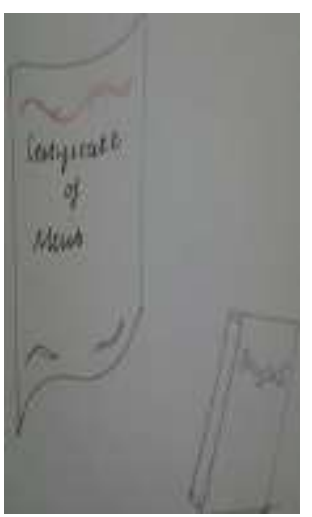

Figure 10A: S3's certificate of merit

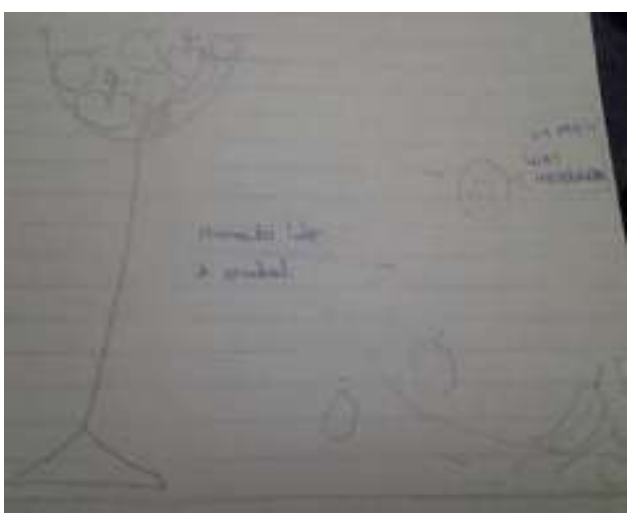

Figure 9B: S8's Glass bowl with fruits

It is important to note that S1 and S2 had the same standpoint that scientists are European males while S3 and S8 had a different stand point that scientists can be either male or female and that they can also be African or European. Women, as a result of their "different lived experiences, have a distinct standpoint" (Roychoudhury, Tippins, \& Nichols, 1995, p. 898). The premise of Feminist Standpoint Theory is that it is the difference in the social experiences of men and women that give them different ways of looking at life and interpreting events and hence different standpoints. However, Smith (1987) notes that science is developed primarily from the perspective of one group, namely, a male Eurocentric view.

In summary, the images of scientists held by Zimbabwean female high school students resemble the images held by students from other countries across the world. Two out of four female students drew stereotypical image of a male scientist and listed Eurocentric names of male scientists because their mental schemas are affected by cultural models to which students are exposed (Gardner, 1980). The diagrams of scientists drawn by female participants may represent a perceived public stereotype and not a personal belief or perception (Symington \& Spurling, 1990). Historically, images of male scientists dominate mass media as indicated by Steinke et al. (2007) and were the ones presented to them in almost all of their school encounters with science. "[The] widespread images of ordinary scientists as white men effectively discourage many talented young women ....from exploring physics as an option" (Ong, 2005, p. 596). In other words, if certain subjects (or careers) are generally perceived (by the dominant view) to be occupied by people of certain traits (e.g. gender, physique, social class, etc.), then students who do not wish to be associated, or who do not have the advertised characteristics, may opt for other subjects (or careers) that are more consistent with their self-identity.

The other two female students gave African names to the scientists that they drew, indicating a deviation from the usual perceptions of a scientist as being a European. This may suggest that scientists are not only Eurocentric but can also be Afrocentric and, more specifically, Zimbabwean. In other words, their drawings and names of scientists reflect their self-belief that Africans can also be scientists, indicating a positive physics identity. Furthermore, the female students seemed to visualise scientists as ordinary people from their daily life experiences and not only as famous scientists depicted in the textbooks. Their diagrams might denote a positive physics perception which may have resulted in the construction of a positive identity formation regarding physics.

The diagrams of scientists drawn by female participants may represent a perceived public stereotype and not a personal belief or perception (Symington \& Spurling, 1990). Their diagrams might denote a positive physics perception which may have resulted in the construction of a positive identity formation regarding physics. The positive physics identity in turn may indicate that the female participants were more attuned to continue studying physics. However, the female students did not seem to perceive scientists as ordinary people but as famous inventive people they encountered in their science text books.

\subsection{Conclusion and policy implications}

The female students studying physics were asked to draw a scientist and to provide a name, age, nationality and gender for the scientist they had drawn. The image of scientists held by Zimbabwean female high school students resemble the images held by students from other countries across the world. Two out of four female students drew stereotypical image of a male scientist and listed Eurocentric names of male scientists because their mental schemas are affected by cultural models to which students are exposed (Gardner, 1980). The diagrams of scientists drawn by female participants may represent a perceived public stereotype and not a personal belief or perception (Symington \& Spurling, 1990). Historically, images of male scientists dominate mass media as indicated by Steinke et al. (2007) and were the ones presented to them in almost all of their school encounters 
with science. "[The] widespread images of ordinary scientists as white men effectively discourage many talented young women ...from exploring physics as an option" (Ong, 2005, p. 596). In other words, if certain subjects (or careers) are generally perceived (by the dominant view) to be occupied by people of certain traits (e.g. gender, physique, social class, etc.), then students who do not wish to be associated, or who do not have the advertised characteristics, may opt for other subjects (or careers) that are more consistent with their self-identity. This might be a possible reason for the under-representation of female students in physics. The other two female students gave African names to the scientists that they drew indicating a deviation from the usual perceptions of a scientist as being a European. Their drawings and names of scientists reflect their self-belief that Africans can also be scientists indicating a positive physics identity.

Being a minority in a class of male students (excluding the student who was in an all-girls school), all the female students studying physics encountered male peer pressure, both in the low and high density schools. The male peer pressure made the environment in the various communities of practice not conducive for female students to learn. For example, some of them were no longer comfortable to ask questions in class but would rather ask the teacher later. Despite this peer pressure, female students actively resisted exclusion and developed a positive physics identity. I therefore recommend that physics teachers should ensure that male students do not harass the female students studying physics in order to create a conducive environment for females to study physics. I agree with Gudyanga, Adam, and Kurup (2015) who recommended that female students need to be afforded a conducive social environment that enables them to form positive social perceptions of physics so that they can develop the self-esteem that is essential for decision making throughout life.

This study also contributes to the strengthening of educational research in Zimbabwe, especially research aimed at emancipation of female students in Zimbabwe. It is my belief that the findings may create the need in heads of schools to sensitise academic staff on the gender dimensions of teaching and learning, which is an important first step towards the transformation of cultural perceptions in order to enable female students to realise their full potential and can make meaningful contributions to the economic, social and cultural development in Zimbabwe. The findings may also be used by teachers, counsellors and parents to encourage females to enrol for physics and mathematics as their subjects of choice. It also contributes to the body of knowledge that relates to the influence of identity and identity formation in an African context.

The main weakness of interpretive research is that it does not seek to generalise settings to a broader population since sample sizes are usually small due to the extended in-depth interviewing. Inferences from this study are limited to the specific population in one geographic area of Gweru district in the Midlands province of Zimbabwe. Only four female A-level students were involved in the study. It is a strength in that "in-depth single cases highlight questions and provide insights that may be useful in other contexts" (Spillane, 2000, p. 30).

Data were based on self-reports which, according to (Hong, 2010, p. 1533), "may result in recall bias such as decay of memory or oversimplification of experiences." People do not have complete access to their experiences according to Polkinghorne (2005, p. 139), who maintains that "the capacity to be aware of or recollect one's experiences is intrinsically limited." Self-reported information may be general and not accurate. Therefore, the validity of the answers depended on the truthfulness of the female students. However, this study was also based on actual behaviour of the female students in their natural CoP, learning both theory and practical lessons in physics

\subsection{Recommendations for further research}

It is recommended that:

- A wider and more comprehensive study nationally is warranted to confirm the findings of this study.

- A broader range of cases could have strengthened the research evidence, with potentially wider acceptance and, hence, this could result in the formulation of more relevant policies.

- Developing this study into a longer term research programme may therefore be interesting.

- Further research to explore the reasons for the common perception that physics is a difficult school subject would be beneficial.

\section{References}

Al-Azzawi, A. (2007). Physical Optics: Principles and Practices. London: Taylor and Francis Group. Babbie, E. (2001). The practice of social research (9th ed.). Belmont, CA: Thompson Wardsworth. Babbie, E., \& Mouton, J. (2001). The practice of social research. South Africa: Oxford University Press. HY.

Bandura, A., \& Bussey, K. (2004). On Broadening the Cognitive, Motivational, and Sociostructural Scope of Theorizing About Gender Development and Functioning: Comment on Martin, Ruble, and Szkrybalo Psychological Bulletin, 130(5), 691-701. 
Bandura, A., \& Bussey, K. (2004). On broadening the cognitive, motivational, and sociostructural scope of theorizing about gender development and functioning: comment on Martin, Ruble, and Szkrybalo (2002).

Barnes, C., \& Kelly, T. (2007). East Coast rural Horizons Young Learners draw their future. In N. D. Lange, C. Mitchell \& J. Stuart (Eds.), Putting people in the picture: Visual Methodologies for social change (pp. 221228). Rottendam: Sense Publishers.

Beauchamp, C., \& Thomas, L. (2009). Understanding teacher identity: Overview of issues in the literature and implications for teacher education. Campridge Journal of Teacher Education, 39(2), 175-189.

Bem, D. J. (1983). Constructing a theory of the triple typology: Some (second) thoughts on nomothetic and idiographic approaches to personality. Journal of Personality, 51(3), 566-577.

Bem, S. L. (1983). Gender Schema Theory and Its Implications for Child Development: Raising Gender-aschematic Children in a Gender-schematic Society. Journal Of Women in Culture and Society, 8(4), 598-616.

Bodzin, A., \& Gehringer, M. (2001). Breaking Sience Stereotypes: Can Meeting Actual Scientists Change Students' perceptions of Scientists? . Science and Children, 36-41.

Braun, V., \& Clarke, V. (2006). Using thematic analysis in psychology. Qualitative Research in Psychology, 3, 77101.

Brotman, J. S., \& Moore, F. M. (2008). Girls and science: A review of four themes in the science education literature. Journal of Research in Science Teaching, 45(9), 971-1002.

Campbell, A., Shirley, L., \& Candy, J. (2004). A longitudinal study of gender-related cognition and behaviour. Developmental Science, 7(1), 1-9.

Carlone, H. B., \& Johnson, A. (2007). Understanding the Science Experiences of Successful Women of Color: Science Identity as an Analytic Lens. Journal of Research in Science Teaching, 44(8), 1187-1218.

Castells, M. (2004). The Power of Identity (2nd ed.). Oxford: Blackwell.

Chambers, D. W. (1983). Stereotype images of the scientist: The draw a scientist test. Science Education, 67(2), 255-265.

Connell, R. W. (2005). Musculinities. Cambridge: Polity Press.

Coyle, J. (2006). Why girls in a single sex school, study Methematical Methods but not Physics. Retrieved from www.vicphysics.org/documents/events/.../D5ResearchCoyle.pdf on 24/08/2011 website:

Creswell, J. W. (2007). Qualitative Inquiry and research design: Chosing among five approaches. London: Sage Publications.

Creswell, J. W. (2013). Qualitative inquiry and research design: Choosing amoung five approaches (3rd edn). London: SAGE Publications.

Dawes, A., \& Biersteker, L. (2011). Early Childhood Development. In A. B. Nsamenang \& T. M. S. Tchombe (Eds.), Hndbook of African Educational Theories and Practices: A Generative Teacher Education Curriculum (pp. 111-122). Bamenda, North West Region (Cameroon): Human Development Resource Centre (HDRC).

Demirbas, M. (2009). The relationships between the scientist perception and scientific attitudes of science teacher candidates in Turkey: A case study. Scientific Research and Essay, 4(6), 565-576.

Denzin, N. K., \& Lincoln, Y. (2000). Qualitative research. Thousand Oaks ua, 413-427.

Denzin, N. K., \& Lincoln, Y. S. (2000). The discipline and practice of qualitative research. Handbook of Qualitative Research, 2, 1-28.

Denzin, N. K., \& Lincoln, Y. S. (2003). The Discipline and Practice of Qualitative Research. In N. K. Denzin \& Y. S. Lincoln (Eds.), The Landscape of Qualitative Research: Theories and Issues. Thousand Oaks: Sage.

Farland-Smith, D. (2009). How does culture shape students' perceptions of scientists? Cross National comparative study of American and Chinese elementary students. Journal of Elementary Science Education, 21(4), 23-42.

Finson, K., \& Pedersen, J. E. (2009). Drawings as visual data: Processes and procedures for educational research. Rotterdam, The Netherlands: Sense Publishers.

Finson, K. D. (2002). Drawing a scientist: What we do and do not know after fifty years of drawings. School science and mathematics, 102(7), 335-345.

Finson, K. D. (2002). Drawing a scientist: What we do and do not know after fifty years of drawings. School Science and Mathematics, 102, 335-345.

Franklin, L. (2012). Gender. London: Palgrave Macmillan.

Galvaan, R. (2007). Getting the Picture.The process of Participation. In N. D. Lange, C. Mitchell \& J. Stuart (Eds.), Putting people in the picture: Visual methodologies of social change (pp. 153-162). Rotterdam Sense Publishers

Gardner, H. (1980). Artful scribbles: The significance of children's drawings. New York: Basic Books.

Gudyanga, A., Adam, K., \& Kurup, R. (2015). Zimbabwean Female Participation in Physics: The Influence of Context on Identity Formation African Journal of Research in Mathematics, Science and Technology Education, 19(2), 172-184.

Hazari, Z., Sonnert, G., Sadler, P. M., \& Shanahan, M. C. (2010). Connecting high school physics experiences, outcome expectations, physics identity and physics career choice: A gender study. Journal of Research in Science Teaching, 47(8), 978-1003.

Hong, J. Y. (2010). Pre-service and beginning teachers' professional identity and its relation to dropping out of the 
profession. Teaching and Teacher Education, 26, 1530-1543.

Horowtz, L. (2010). Pschemas, Psychopathology and Psychotherapy Research. Psychotherapy Research, 4(1), 119.

Hughes, G. (2001). Exploring the Availability of Student Scientist Identities within Curriculum Discourse: An antiessentialist approach to gender-inclusive science. Gender and Education, 13(3), 275-290.

Jenkins, R. (2004). Social Identity. London: Routledge.

Kalu, I. (2005). Classroom interaction in physics lessons, relative to students' sex. AfricanJournal of Research in Mathematics, Science and Technology, 9(1), 55-66.

Knight, G. P., Bernal, M. E., Garza, C. A., \& Cota, M. K. (1993). A Social Cognitive Modelof the Development of an Ethnic Identity and Ethnically-Based Behaviours. In M. E. Bernal \& G. P. Knight (Eds.), Ethnic Identity: Formationand Transmission amoung Hispanic and other Minorities. New York: State University of New York Press.

Knoblauch, H., Baer, A., Laurier, E., Petschke, S., \& Schnettler, B. (2008). Visual Analysis. New Developments in the Interpretative Analysis of Video and Photography. Forum: Qualitative Social Research, 9(3), 14.

Leary, M. R., \& Tangney, J. P. (2003). Handbook of Self Identity. New York: Giulford Press.

Lips, H. M. (2008). Sex and Gender: An Introduction, . New York: McGraw-Hill.

Love, J. G. (1994). The hermeneutics of transcript analysis. The Qualitative Report, (1). http://www.nova.edu/ssss/QR/BackIssues/QR2-1/love.html

Martin, C. L., \& Ruble, D. (2004). Children's search for gender cues cognitive perspectives on gender development. Current directions in psychological science, 13(2), 67-70.

Martin, C. L., \& Ruble, D. (2004). Children's Search for Gender Cues: Cognitive Perspectives on Gender Development. Current Directions in Psychological Science, 13(2), 67-70.

McCullough, L. (2004). Gender , Context and Physics Assessment. Journal of International Women's Studies, 5(4), 20-30.

Miles, M. B., \& Huberman, A. M. (1994). Qualitative Data Analysis: An Expanded Sourcebook (2nd ed.). Thousand Oaks, California, United States of America: Sage Publications, Inc.

Miller, P. H., Blessing, J. S., \& Schwartz, S. (2006). Gender Differences in High-school Students' Views about Science. International Journal of Science Education, 28(4), 363-381.

Mitchell, C., Theron, L., Smith, A., \& Stuart, J. (2011). Picturing Research: An Introduction. In L. Theron, C. Mitchell, A. Smith \& J. Stuart (Eds.), Picturing Research: Drawing as visual methodology. Rotterden: Sense Publishers.

Mouton, J. (2002). How to Succeed in Your Master's and Doctoral Studies: A South African Guide and Resource Book. Pretoria: Van Schaik.

Muropa, B. C., Kusure, L. P., Makwerere, D., Kasowe, R., \& Muropa, Z. (2013). Unhu/Ubuntu and Its Relationship with Civics and Citizenship Education. Journal of Emerging Trends in Educational Research and Policy Studies (JETERAPS), 4(4), 658-661.

Murphy, P., \& Whitelegg, E. (2006a). Girls and physics: Continuing barriers to belonging. The Curriculum Journal, 17(3), 281-305.

Murphy, P., \& Whitelegg, E. (2006b). Girls in the physics classroom: a review of the research into the participation of girls in physics 1-56. Retrieved from http://oro.open.ac.uk/6499/1/Girls_and_Physics_Report.pdf website:

Mwetulundila, P. N. (2011). Why girls are'nt fully participating in science and Mathematics in Namibia Retrieved from Retrieved from http://www.nied.edu.na/publications/journals/journal11/journal\%204PDF website:

Nafukho, F. M. (2006). Ubuntu Worldview:A Traditional African view of adult learning in the workplace. Advances in Developing Human Resourses, 8(3), 408-415.

Nafukho, F. M., Amutabi, M. N., \& Otunga, R. N. (2005). Foundations of Adult Learning in Africa. Cape Town, South Africa: Pearson/Unesco. .

National Gender Policy. (2004). National Gender Policy 2004. Harare: Government Printers.

National Gender Policy. (2013). National Gender Policy of Zimbabwe (2013-2017). Harare: Government Printers.

Nieuwenhuis, J. (2007). Qualitative research design and data gathering techniches. In K. Maree (Ed.), First steps in research. Pretoria: Van Schaik Publishers.

Olivier, T., Wood, L., \& De Lange, N. (2007). Changing our eyes and seeing hope. In N. D. Lange, C. Mitchell \& A. Stuart (Eds.), Putting people in the Picture Visual methodologies for Social Change. Rotterdam: Sense Publishers.

Olorode, D. O. (2005). A comparative study of girls' participation in physics at secondary and tertiary institutions in Lagos State. Retrieved from http://www.wcpsd.org/posters/education/Olorode.pdf on 17-08-2011 website:

Ong, M. (2005). Body Projects of Young Women of Color in Physics: Intersections of Gender, Race, and Science. Social Problems, 52(4), 593-617.

Paechter, C. (2003). Learning masculinities and femininities: Power/knowledge and legitimate peripheral participation. Women's Studies International Forum, 26(6), 541-552.

Pedersen, J. E., \& Finson, K. D. (2009). Visual data: Understanding and applying visual data to research in 
education: Sense Publishers.

Petersoo, P. (2007). Reconsidering Otherness: Constructing Estonian Identity. Nations and Nationalism, 13(117133).

Polkinghorne, D. E. (2005). Language and meaning: Data collection in qualitative research. Journal of Counseling Psychology, 52(2), 137-145.

Prusak, A. (2003). Prusak, A. (2003). The nature and role of cultural factors in the learning of mathematics. Unpublished doctoral dissertation (in Hebrew). University of Haifa, Haifa, Israel.

Puusa, A., \& Tolvanen, U. (2006). Organisational Identity and Trust. Electronic Journal of Business Ethics and Organisation Studies, 11(2), 29-33.

Riessman, C. K. (2006). Narrative Analysis In V. Jupp (Ed.), The Sage Dictionary of Social Research Methods (pp. 186-189). London, United Kingdom SAGE Publications Ltd

Riley, T., \& Hawe, P. (2005). Researching practice: the methodological case for narrative inquiry. Health Education Research, 20(2), 226-236.

Roychoudhury, A., Tippins, D. J., \& Nichols, S. E. (1995). Gender-Inclusive Science Teaching: A FeministConstructivist Approach. Jounal of Rresearch in Science Teaching, 32(9), 897-924.

Ryan, G. W., \& Bernard, H. R. (2003). Techniques to identify themes. Field Methods, 15(1), 85-109.

Scantlebury, K., \& Baker, D. (2007). Gender Issues in Science Education Research: Remembering where the difference lies. In K. A. Sandra \& G. L. Norman (Eds.), Handbook of Research on Science Education. London: Lawrence Erlbaum Associates, Publishers.

Schilling, J. (2006). On the pragmatics of qualitative assessment: Designing the process for content analysis. European Journal of Psychological Assessment, 22(1), 28-37.

Schmitt, B. H., Leclerc, H. F., \& Dubé-Rioux, L. (1981). Sex Typing and Consumer Behaviour: A Test of Gender Schema Theory. Journal of Consumer Research, 15(1), 122-128.

Smit, B., \& Fritz, E. (2008). Understanding teacher identity from a symbolic interactionist perspective: two ethnographic narratives. South African Journal of Education, 28, 91-101.

Smith, D. (1987). The Truth that Never Hurts. New Jersey: Rutgers University Press.

Spillane, J. P. (2000). A Fifth-Grade Teacher's Reconstruction of Mathematics and Literacy Teaching: Exploring interactions among identity, learning and subject matter. The Elementary School Journal, 100(4), 307-330.

Steinke, J., Lapinski, M., Crocker, N., Zietsman-Thomas, A., Williams, Y., Higdon, S., \& Kuchibhotla, S. (2007). Assessing media influences on middle school-aged children's perceptions of women in science and engineering using the Draw-A-Scientist-Test (DAST). Science Communication, 29, 35-64.

Sternberg, R. J. (1993). What is rhe relationship of gender to biology and environment?: An evolutionary model of how what you answer depends on just what you ask. In A. E. Beall \& R. J. Sternberg (Eds.), The psychology of gender. New York: Guiford Press.

Stuart, J. (2007). Drawings and transformation in the health arena. In N. D. Lange, C. Mitchell \& J. Stuart (Eds.), Putting people in the picture: Visual methodologies for social change. Netherlands: Sense Publishers.

Symington, D., \& Spurling, H. (1990). The 'draw a scientist test': Interpreting the data. Research in Science and Technological Education, 8, 75-77.

Türkmen, H. (2008). Turkish primary students' perceptions about scientist and what factors affecting the image of the image of the scientists. Eurasia Journal of Mathematics, Science \& Technology Education, 4(1), 55-61.

Van Zoest , L. R., \& Bohl , J. V. (2008). Mathematics Teacher Identity: a framework for understanding secondary school mathematics teachers' learning through practice. Teacher Development: An international journal of teachers' professional development, 9(3), 315-345.

Walker, M. (2001). Engineering Identities. British Journal of Sociology of Education, 22(1), 75-89.

Weber, S. (2005). Visual Images in Research. In J. G. Knowles \& L. C. Ardra (Eds.), Handbook of the Arts in Qualitative Research. London: SAGE Publications Ltd.

Wenger, E. (1998). Communities of Practice: Learning, Meaning and Identity. Cambridge: Cambridge University Press.

Wenger, E. (1998). Communities of practice: Learning, meaning, and identity: Cambridge university press.

Wenger, E. (2010). Conceptual Tools for CoPs as Social Learning Systems: Boundaries, Identity, Trajectories and Participation. In C. Blackmore (Ed.), Social Learning Systems and Communities of Practice (pp. 125-143). London, United Kingdom: Springer

Zhang, Y., \& Wildemuth, B. (2009). Unstructured Interviews [PDF document].

Zhang, Y., \& Wildemuth, B. M. (2009). Qualitative analysis of content. Retrieved from School of Information, University of Texas at Austin: http://www.ischool.utexas.edu/ yanz/Content_analysis.pdf on 20/12/2012 website:

Zohar, A., \& Bronshtein, B. (2005). Physics teachers' knowledge and beliefs regarding girls' low participation rates in advanced physics classes. International Journal of Science Education, 27(1), 61-77. 